\title{
Bioenergetics of British Shrews in Grassland
}

\author{
John C. PERNETTA ${ }^{1}$
}

\begin{abstract}
Pernetta J. C., 1976: Bioenergetics of British shrews in grassland. Acta theriol., 21, 33: 481-497 [With 6 Tables \& 3 Figs.].

Some aspects of shrew energetics are discussed in the light of field and laboratory experimentation. The daily consumption, faecal production and throughput rates of Sorex araneus ( $\mathrm{L}$ in n a e u s, 1758) Sorex minutus ( $\mathrm{L}$ in $\mathrm{n}$ a e $\mathrm{us}, 1766$ ) and Crocidura suaveolens cassiteridum (H into $\mathrm{n}$, 1924) were measured in the laboratory. Part of the variation in stated consumption/day in the literature was shown to be due to the variable water contents of the artificial diets. The assimilation efficiency of C. suaveolens was measured $(89 \%)$ and found to be similar to quoted values for other shrews. This efficiency was found to increase when the animals were deprived of water. A diagram of energy flow through shrew populations in Wytham grassland is based on dietary analysis of 244 and 130 snap trapped $S$. araneus and $S$. minutus respectively. Finally annual consumption and production figures for the two species are presented and reasons for the high $P / C$ ratios suggested.

[Dept. Zool., Anim. Ecol. Res. Group, South Parks Road, Oxford, OXL 3PS, England].
\end{abstract}

\section{INTRODUCTION}

The work reported here formed part of a larger study of the ecology of British shrews, and extensive use is made in this paper of the data on field diets and population biology of Sorex araneus and Sorex minutus (P e r n e t t a, 1973, 1976). In view of the current interest in bio-energetics and the relative dearth of such information for small insectivores it was felt that a combination of the above data and details of the daily food intake, faecal output, assimilation efficiency and calorific measurements obtained in the laboratory would produce an interesting picture of the ecological energetics of these animals.

\section{MATERIAL AND METHODS}

The field diets of Sorex araneus and Sorex minutus were determined by analysis of 244 and 130 snap trapped individuals of each species respectively. This snap trapping was carried out over 18 months in Brachypodium pinnatum

1 Present address: Univ. Manitoba, Dept. Zool., Winnipeg, Canada R3T 2 N2. [481] 
dominated grassland on the Oxford University Estate at Wytham. Data on the densities of these species in a similar habitat, was obtained by means of a concurrent mark, release, recapture programme using Longworth live traps. These data are more fully reported elsewhere (P e r n e $t \mathrm{t} a, 1973,1976)$.

Details of the daily food intake were obtained from laboratory maintained individuals which had been in captivity for at least 30 days. Daily faecal output was determined by total collection in the case of Crocidura suaveolens and by extrapolation from four hour observation periods in the case of $S$. araneus and $S$. minutus. The calorific value of the food and faeces of $C$. suaveolens were determined using a Philipson microbomb calorimeter and the assimilation efficiency of this species calculated.

\section{RESULTS}

\section{Metabolic Expenditure}

Table 1.presents values taken from the literature of the body weight, daily food intake and ratio of food intake to body weight for various shrew species. A regression analysis was performed on these data using the equation: $\log$ (ratio food intake : body weight +1$)=0.4773-0.0141$ (Body weight).

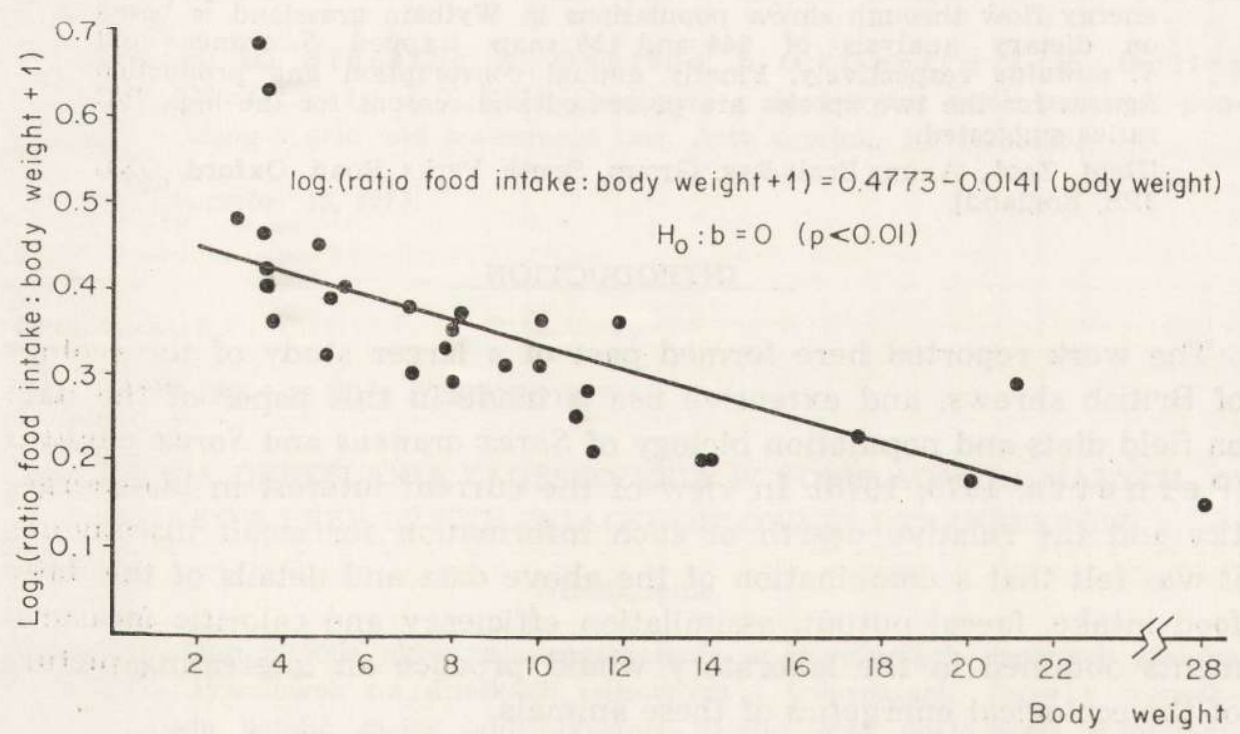

Fig. 1. Regression analysis of the ratio of food intake to body weight on the body weight of various shrew species; data from Table 1.

The resulting regression line (Fig. 1), when tested against the null hypothesis that, the ratio of food intake to body weight is constant for increasing body weight, is found to differ significantly $(p<0.01)$. Such a negative correlation might be expected from the decreasing ratio of surface area 
to volume, and hence one presumes a decreasing proportional heat loss. This regression line can be used to calculate the daily food consumption where the weight of the animal is known.

The generally high food intake in shrews has lead many authors to the conclusion that the daily metabolic rate of these animals must be

Table 1

Food consumption and ratio to body weight, for various shrews.

\begin{tabular}{|c|c|c|c|c|}
\hline Species & $\begin{array}{l}\text { Body wt. } \\
\text { g }\end{array}$ & $\begin{array}{c}\text { Food wt. } \\
\mathrm{g}\end{array}$ & $\begin{array}{l}\mathrm{g} \text { food/g bod } \\
\text { wt/day }\end{array}$ & References \\
\hline Cryptotis floridana & 5.0 & 5.5 & 1.1 & Springer, 1937 \\
\hline Diplomesodon pulchellum & 10.0 & $10-17$ & 1.3 & Hepner, 1939 \\
\hline Microsorex hoyi & 3.5 & 6.5 & 1.86 & Buckner, 1964 \\
\hline Blarina brevicauda & $\begin{array}{l}20.1 \\
18.0 \\
\overline{21.0} \\
28.0 \\
\overline{15.8}\end{array}$ & $\begin{array}{l}10.1 \\
\overline{-} \\
\overline{-} \\
=\end{array}$ & $\begin{array}{l}0.5 \\
0.3-0.5 \\
0.7 \\
0.96 \\
0.42 \\
0.9 \\
1.16\end{array}$ & $\begin{array}{l}\text { Hamilton, } 1930 \\
\text { Babcock, } 1914 \\
\text { Morrison et al. } 1957 \\
\text { Shull, "1907 } \\
\text { Tupikova, } 1949\end{array}$ \\
\hline $\begin{array}{c}\text { Neomys fodiens } \\
\text { t }\end{array}$ & $\begin{array}{l}14.1 \\
13.8 \\
17.6 \\
11.1 \\
10.9\end{array}$ & $\begin{array}{r}8.2 \\
8.0 \\
12.7 \\
9.9 \\
8.4\end{array}$ & $\begin{array}{l}0.58 \\
0.58 \\
0.72 \\
0.89 \\
0.77\end{array}$ & $\begin{array}{c}\text { Hawkins \& Jewell, } 1962 \\
", \\
” \\
"\end{array}$ \\
\hline Crocidura suaveolens & $\begin{array}{l}80 \\
5.1\end{array}$ & $\underline{7.4}$ & $\begin{array}{l}0.93 \\
1.33\end{array}$ & Tupikova, 1949 \\
\hline Sorex cinereus & $\begin{array}{l}3.6 \\
3.6\end{array}$ & $\begin{array}{r}11.7 \\
5.8\end{array}$ & $\begin{array}{l}3.3 \\
1.61\end{array}$ & $\begin{array}{l}\text { Blossom, } 1932 \\
\text { Buckner, } 1964\end{array}$ \\
\hline Sorex arcticus & 5.4 & 8.2 & 1.52 & $"$ \\
\hline Sorex minutus & $\begin{array}{l}3.6 \\
4.8 \\
30\end{array}$ & $\begin{array}{l}5.4 \\
8.9 \\
-\end{array}$ & $\begin{array}{l}1.5 \\
1.85 \\
2.03\end{array}$ & $\begin{array}{l}\text { Hawkins \& Jewell, } 1962 \\
\text { Tupikova, } 1949\end{array}$ \\
\hline Sorex sp. & $\begin{array}{l}3.66 \\
3.35\end{array}$ & - & $\begin{array}{l}1.27 \\
3.84\end{array}$ & Morrison et al. 1957 \\
\hline itici & $\begin{array}{r}6.5 \\
8.0 \\
11.8 \\
7.8 \\
9.2 \\
11.0 \\
8.33 \\
8.43 \\
-.-\end{array}$ & $\begin{array}{r}6.5 \\
9.9 \\
15.2 \\
8.9 \\
9.7 \\
6.8 \\
- \\
4.3 \\
-\end{array}$ & $\begin{array}{l}1.0 \\
1.24 \\
1.29 \\
1.14 \\
1.05 \\
0.62 \\
1.42 \\
0.543 \\
2.5\end{array}$ & $\begin{array}{l}\text { Hawkins \& Jewell, } 1962 \\
\qquad " \\
\text { " } \\
\text { Rörig, } 1905 \\
\text { Tupikova, } 1949 \\
\text { Wołk, 1969 } \\
\text { Svihla, 1934 }\end{array}$ \\
\hline Sorex palustris & 10.0 & 10.3 & 1.03 & Conaway, 1952 \\
\hline
\end{tabular}

high (Morrison et al., 1957; Gębczyński, 1965). Hawkins \& J e w ell (1960) have shown that the resting metabolic rate is the same as that for white mice of the same size. Even if this is correct the overall energy:expenditure per day is likely to be greater than that of rodents since the activity of shrews is higher ( $\mathrm{Cr}$ ow croft, 1954; G ę b c z y ń- 
sk i, 1965). More recent and comprehensive work V o g e l (1976) suggests that a very real difference exists between shrews of the subfamily Soricinae and other mammals in terms of their basal metabolic rates, that of the shrews being much higher. He further shows that the Crocidurinae have a basal metabolic rate lower than that of the Soricinae and , approaching that of other mammals.

If Sorex minutus is assumed to have a mean weight of $4 \mathrm{~g}$ then the average heat loss per day becomes $7.2 \mathrm{kcal} / \mathrm{animal}$. This value is somewhat higher than the $5-6 \mathrm{kcal} / \mathrm{animal} /$ day quoted by $\mathrm{Geqbczyn} \mathrm{ski}$ (1971) for pre-winter juveniles, but agrees with the mean of values presented in his earlier paper, Gę bc zyńs k i (1965). The assumption of an annual mean weight of $4 \mathrm{~g}$ for $S$. minutus is based on the work of Crow croft (1957), Shillitto (1960) and Borowski \& Dehnel (1953). C row croft (1957) presents data with a mean weight of $3.5 \mathrm{~g}$ and range of $2.6 \mathrm{~g}-5.6 \mathrm{~g}$, values which are somewhat lower than those of this species. A mean of their monthly means is 4.6 , range $2-5 \mathrm{~g}$. monthly weights for large samples representing two separate generations of this species. A mean of their monthly means is 4.6 , range $2-5 \mathrm{~g}$. Elsewhere in the present paper a mean weight for $S$. araneus in taken as $7.5 \mathrm{~g}$, following $\mathrm{Crow}$ cr of t (1954) and in close agreement with B orowski \& Dehnel (1953), $7.6 \mathrm{~g}$ and $8 \mathrm{~g}$ being the annual means of their samples. This annual mean weight for Sorex araneus corresponds to an average daily heat loss of $9.9 \mathrm{kcal} / \mathrm{animal} /$ day which agrees well with the individual values determined by Gę bc zyński (1965) of $9.2 \mathrm{kcal} /$ animal/day.

\section{Daily Food Intake}

Some of the confusion surrounding the magnitude of the variation in the daily food intake in single species of shrews may be due to the shrews initial behaviour in captivity. When first brought into the laboratory individuals feed at a higher rate than later, and put on weight (Crowcroft, 1957) or may, during their captivity exhibit rapid increases and decreases in body weight ( $\mathrm{P} \mathrm{u} \mathrm{c} \mathrm{e} \mathrm{k,} \mathrm{1964).}$

The nature of the artificial diets upon which assessments of daily intake are based, may also contribute to the variation observed by different workers. For example the very high ratio of food intake to body weight quoted by Morrison et al. (1957) for Sorex sp. (Table 1) is based on measurements taken from animals fed on a diet of earthworms whereas the smaller value is taken from animals fed on rat liver. The low values of $\mathrm{W}$ o $\mathrm{k}(1969)$ are due to the fact that she fed her shrews on partially dried meat. (For this reason the values are not included in the regression calculation for Figure 2). It would appear from this that the water content 
of the diet (as might be expected) affects the daily food intake when expressed in wet weights.

During the present work it was noted that when shrews were fed on a diet consisting solely of fly larvae the daily intake of food (wet weight) was greater than that obtained when the animals were fed on a diet of last instar Tenebrio molitor larvae. The calculated daily intake for these two diets in terms of dry weight was however approximately equal (Table 2). The degree of chitinisation of items in the diet might

Table 2

Daily food intake of C. suaveolens and $S$. araneus expressed in dry and wet weights. (Mean based on 2 days testing on 10 individuals of each spp.)

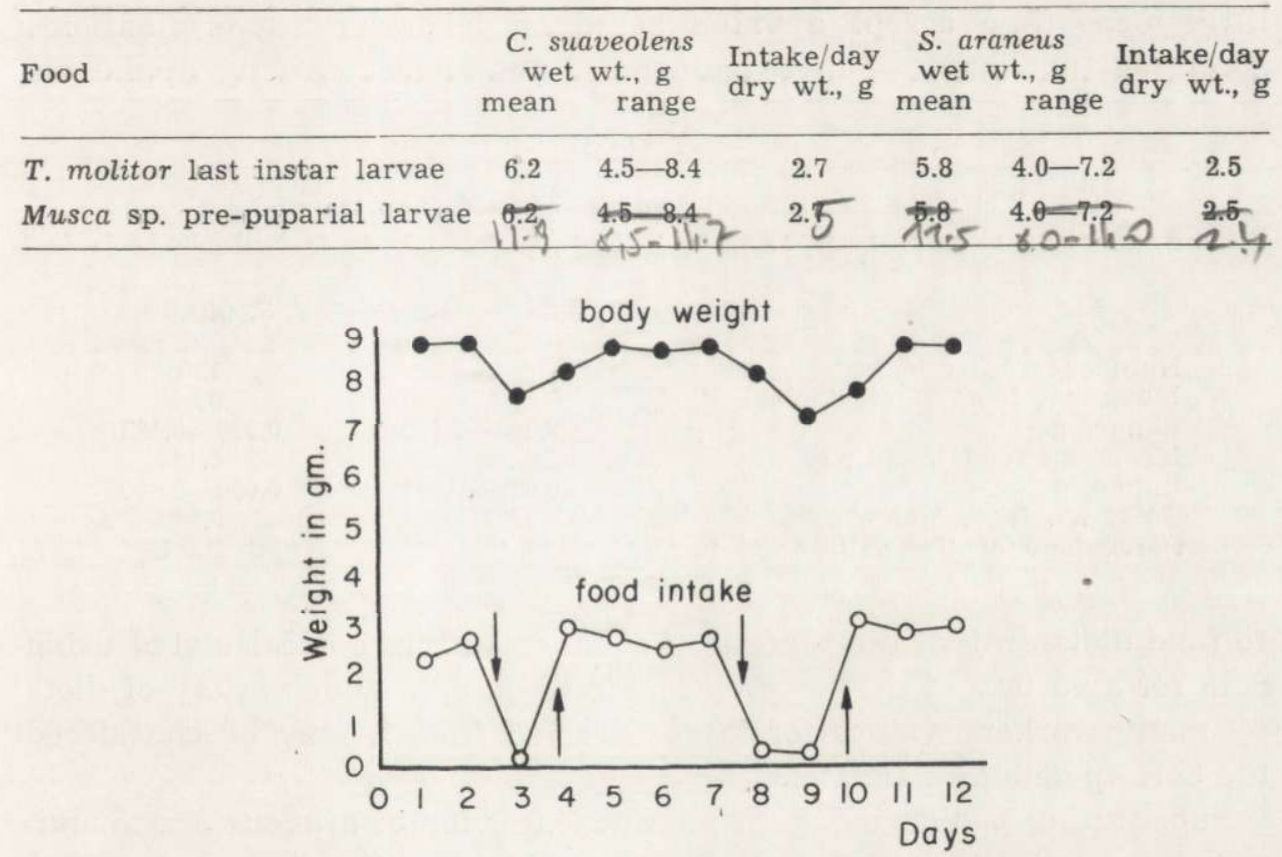

Fig. 2. The effect of drinking water on food consumption and body weight of C. suaveolens. Arrows indicate water removed or replaced.

also affect the daily food intake; a shrew might be expected to have a higher daily intake when feeding on highly chitinised invertebrates then when feeding on lightly chitinised ones; due to the indigestibility of chitin; further investigations are necessary to elucidate this point.

In addition to the two factors mentioned above the daily food intake was found to vary in the presence or absence of free water for the animals to drink. When Crocidura suaveolens was deprived of water the 
daily food intake dropped dramatically and the body weight of animals subjected to a variable regime of water presence and absence fluctuated in phase with the fluctuation: in intake (Fig. 2). This suggests that an external water source is vitally important to these animals and that in its absence body fats may be rapidly metabolised to provide metabolic water. Indeed experience in keeping shrews has shown that both $S$. araneus and $S$. minutus die within a few days of being deprived of water. The only occasion on which $C$. suaveolens was observed to feed direct from the rectum (as described by $\mathrm{Crow}$ croft, 1957 for $S$. araneus) occurred when the animals were deprived of water (8 observations).

In attempting to assess the daily food intake in the field one can do little more than accept a value based on laboratory determinations, accepting that many of these values are not in fact directly applicable

Table 3

Wet weight of the gut contents of field snap trapped

$S$. araneus and $S$. minutus

\begin{tabular}{lcc}
\hline & S. araneus & S. minutus \\
\hline Number & 244 & 130 \\
Mean wt. food in stomach, g & 0.1277 & 0.09 \\
Range, g & $0.000-0.425$ & $0.000-0.125$ \\
Mean wt. food in gut, g & 0.480 & 0.139 \\
Range, g & $0.090-0.902$ & $0.054-0.800$ \\
Total wt. food, Mean, g & 0.608 & 0.229 \\
Percentage of the daily food intake & $6.1 \%$ & $2.3 \%$ \\
\hline
\end{tabular}

to field diets. In that the regression equation in Fig. 1 is calculated using data for a variety of shrew species maintained on a wide variety of diets by many workers, values for intake derived from it may be considered the "best possible" estimate.

Substituting body weights of 7.5 and $4.0 \mathrm{~g}$ for S. araneus and S. minutus respectively, into the equation one obtains values for consumption of $10 \mathrm{~g}$ for $S$. araneus and $6 \mathrm{~g} / \mathrm{d}$ ay for $S$. minutus. In the case of $S$. araneus this value is $5 \%$ larger than one obtained by taking a mean of the values in Table 1 , but in the case of $S$. minutus a mean taken from the values in Table 1 is $20 \%$ greater than the present one.

Table 3 presents the approximate weights of the gut contents of snap trapped shrews from grassland. Such values are highly suspect being obtained by the difference in weight between empty and full guts; which are affected by the extent to which the stomach and gut are adequately dried (an impossible factor to keep constant) before each weighing. The results do serve to indicate the order of fullness, which represents 
approximately $5 \%$ of the daily food intake. This in itself suggests that these animals are rarely in a state of repletion in the wild and supports the observations on field activity which suggest that these animals spend much of their time searching for food (Crow croft, 1957; G ę b c z y ński, 1965; B u chalczy k, 1972; Pernet t a, 1973).

\section{Through Put Rate}

On the basis of the values for the weight of food found in the gut of field trapped animals it is possible to calculate a theoretical value for the rate at which food passes through the gut. If on average any animal in the field at any instant in time has $5 \%$ of the daily ration in its alimentary tract, then there must be total replacement of this material every 72 minutes.

\section{Table 4}

Rate of movement of various items through the gut of S. araneus

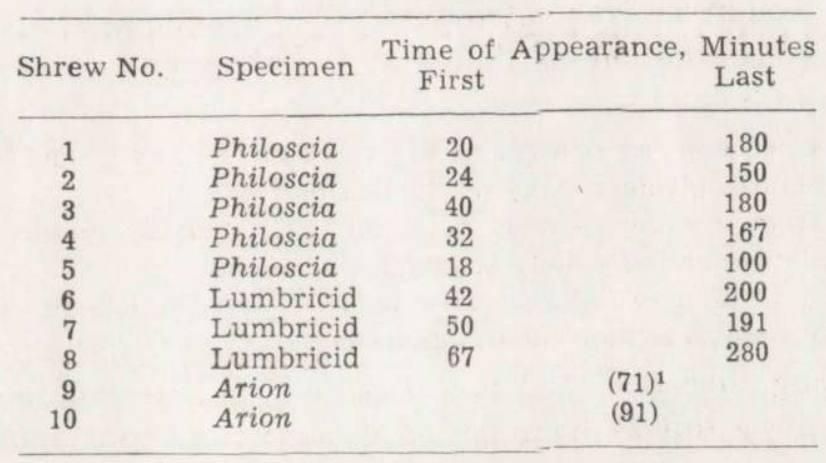

1 Time of appearance of radula

An attempt was made during the present study to test this theoretical value in the laboratory. Captive animals were fed solely on a diet of one species (usually fly larvae) and then presented with a different item. The times of first and last appearance of parts of this item were then recorded by faecal collection and examination (Table 4 ).

It became apparent as the trials proceeded that the results would be difficult to interpret conclusively and that the amount of labour required to quantify them sufficiently to produce average throughput rates for even the major items would be prohibitive. They were therefore not pursued. However, in conjunction with the studies of R u d g e (1968) for Sorex araneus and Kostelecka-Myrcha \& Myrcha (1964) on Neomys fodiens they indicate several observable tendencies. (a) Smaller items with brittle exo-skeletons pass through more rapidly than larger 
tougher items such as Arion. (b) That the rate of passage is between 30 minutes and 3 hours. (c) That each item becomes so mixed with the total gut contents that its total egestion time is extended over a long period.

Whilst the results are somewhat inconclusive in themselves they do serve as additional information supporting the contention that shrews are rarely in a state of repletion in the field, in that the theoretically derived time of total replacement of gut contents lies midway between the times of first and last appearance of items in the trials above.

\section{Faecal Production}

Observations made during the above and other behavioural experiments indicate the rate and quantity of faecal production. The time of production of the first faecal pellet after introduction to an experimental arena is highly variable, and depends upon the state of the animal. The minimum time for production of the first pellet was 4 minutes, the maximum 180 minutes $(n=62)$, the average 22 minutes. In the majority of cases at least one food item was eaten prior to defecation, and once feeding had commenced defecation continued at a fairly regular rate. The results are summarised below:

S. minutus: 6 observation periods, total $10 \frac{1}{2}$ hours. Pellets produced approximately every 10 minutes giving a daily production of 144 .

S. araneus: 24 observation periods, total 96 hours. Pellets produced approximately every 18 minutes giving a daily production of 80 .

C. suaveolens: 47 observation periods, total 160 hours. Pellets produced approximately every 15 minutes giving a daily production of 96 .

In attempting to collect the faecal pellets and determine the weight produced during a full 24 hour period it was found that animals kept in small, or uniform smooth sided polythene containers which permitted total collection failed to behave normally. The daily food intake fluctuated wildly and the animals level of activity was extremely high. Although this was the case with both Sorex species, C. suaveolens appeared to behave normally. The number of faecal pellets produced by this species averaged $120 /$ day $(n=20)$.

This value is some $20 \%$ higher than the value determined on the basis of the observation periods quoted above. The values quoted for the other two species on the same basis may also be underestimates, resulting from the short periods of observation over which the collections were made.

\section{Assimilation Efficiency of C. suaveolens}

Since food intake and faecal production were measured for this species in the presence and absence of drinking water an estimate of the assimilation efficiency under both conditions can be calculated, Dr. R. 
Abel of this department performed the calorimetric measurements on a Phillipson micro-bomb calorimeter.

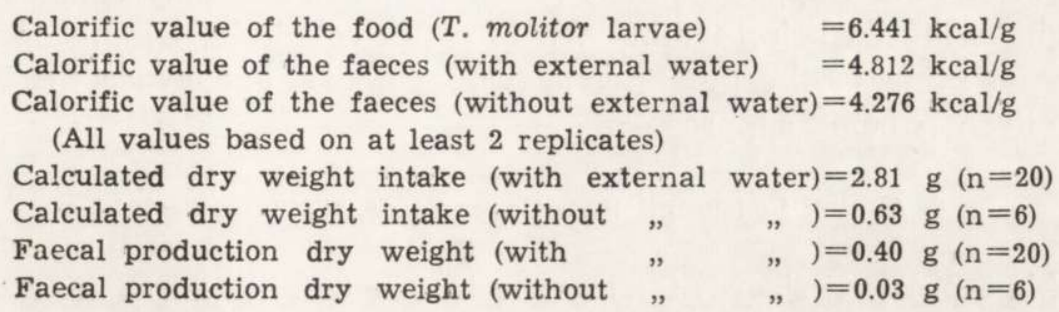

(Faecal dry weights and intake dry weight equivalents determined by drying ii a vacuum oven at $60^{\circ} \mathrm{C}$ )

Assimilation Efficiency in the presence of external water $=$

$$
\frac{\text { Consumption }- \text { Faeces }}{\text { Consumption }}=\frac{18.1 \mathrm{kcal}-1.92 \mathrm{kcal}}{18.1 \mathrm{kcal}} \times 100=89.4 \%
$$

Assimilation Efficiency in the absence of external water $=$

$$
\frac{\text { Consumption }- \text { Faeces }}{\text { Consumption }}=\frac{4.06 \mathrm{kcal}-0.13 \mathrm{kcal}}{4.06 \mathrm{kcal}} \times 100=97.8 \%
$$

Both of these values are extremely high, but comparable with those of $\mathrm{Buckn}$ er (1964). An explanation of this high efficiency is difficult to produce but may lie in the low proportion of indigestible chitin in the artificial diet provided. Almost certainly assimilation efficiency in the field will be lower since the natural diet includes a high proportion of small items and hence a higher proportion of indigestible chitin. In order to determine the magnitude of this effect it would be instructive to maintain shrews in the laboratory on diets of small invertebrates, and conduct a more detailed study of this aspect of shrew bio-energetics.

The difference in the assimilation efficiency in the presence and absence of a free water source for the animals to drink (although not statistically proven) may result from the observed tendency for rectal feeding in the absence of water. Examination of the above figures shows that faecal production in the absence of water is disproportionately lowered, suggesting either, that the material is being recycled by rectal feeding on a large scale or that the rate of passage through the alimentary tract is considerably slower, or both. Assuming that the dry weight of faeces produced per day should remain in the same proportion to the food intake, with or without water, then; with water present $0.40 \mathrm{~g}$ faeces are equivalent to $2.81 \mathrm{~g}$ food. Without water present $0.03 \mathrm{~g}$ faeces are equivalent to $(0.03 \times 2.81): 0.4=0.21 \mathrm{~g}$. However the measured intake was $0.63 \mathrm{~g}$, therefore $0.42 \mathrm{~g}$ (dry wt.) of food remain in the gut. This is approximately equivalent to $1.5 \mathrm{~g}$ of food by wet weight, a value three times 
greater than the average value for the wet weight of food contained in the gut of field trapped animals (Table 3 ). Thus one may conclude that the gut is indeed being maintained in a full condition, by the operation of one or other of the processes suggested above, and hence the hunger drive itself is being suppressed.

\section{Annual Consumption on Upper Seeds, Wytham, Berkshire}

Table 5 presents figures for the annual consumption of $S$. minutus and $S$. araneus in terms of the dietary composition, densities and daily intake

Table 5

Density and annual consumption by $S$. araneus and $S$. minutus in Brachypodium pinnatum grassland, Wytham, near Oxford. All consumption values expressed in $\mathrm{g} / \mathrm{ha}$.

\begin{tabular}{|c|c|c|c|c|}
\hline Months & J.F.M. & A.M.J. & J.A.S. & O.N.D. \\
\hline \multicolumn{5}{|c|}{ S. araneus } \\
\hline Density/ha & 5.3 & 5.6 & 8.0 & 6.3 \\
\hline Consumption/individual (wet. wt.) & 873 & 883 & 892 & $\begin{array}{r}892 \\
-\quad 890-10\end{array}$ \\
\hline $\begin{array}{l}\text { Total cons/ha } \\
\text { Consumption of: }\end{array}$ & 4,627 & 4,945 & 7,186 & 5,620 \\
\hline Lumbricidae & 1,147 & 924 & 2,021 & 2,636 \\
\hline Enchytraeidae & 190 & - & 36 & 1,001 \\
\hline Mollusca & 37 & 178 & 121 & 118 \\
\hline Opiliones & 870 & 460 & 1,307 & 175 \\
\hline Aranae & 606 & 361 & 429 & 203 \\
\hline Coleoptera Adults & 1,051 & 2,224 & 2,220 & 1,265 \\
\hline Larvae & 292 & 747 & 485 & 68 \\
\hline Others & 433 & 40 & 521 & 156 \\
\hline \multicolumn{5}{|c|}{ S. minutus } \\
\hline Density/ha & 4.0 & 6.7 & 9.9 & 4.5 \\
\hline Consumption/individual (wet. wt.) & 540 & 546 & $\begin{array}{r}552 \\
-\end{array}$ & 552 \\
\hline $\begin{array}{l}\text { Total cons/ha } \\
\text { Consumption of: }\end{array}$ & 2,160 & 3,658 & 5,465 & 2,484 \\
\hline $\begin{array}{l}\text { Consumption of: } \\
\text { Opiliones }\end{array}$ & 315 & & & \\
\hline Aranae & 145 & $\begin{array}{l}410 \\
867\end{array}$ & $\begin{array}{l}1,475 \\
1,251\end{array}$ & $\begin{array}{r}1,093 \\
132\end{array}$ \\
\hline Coleoptera Adults & 1,043 & 1,262 & 2,131 & 1,160 \\
\hline Larvae & 564 & 823 & 333 & 57 \\
\hline Others & 93 & 293 & 275 & 42 \\
\hline
\end{tabular}

(the latter calculated from the regression line in Fig. 1 as described above). Dietary composition and densities were taken from the majo: study referred to (P e r n et t a, 1973). The figures for consumption are presented in wet weights. To calculate the energy consumption of the shrew populations, values for the daily intake in dry weight (Table 2) were used, this assumes a water content for the diet as a whole of $75 \%$. Since the diet was assessed quantitatively the calorific contribution of 
each prey group to the maintainance of the shrews can be assessed. Such values are presented in Table 6 .

If the lumbricid, enchytraeid and molluscan fraction of the diet is assumed to have a calorific value of $5.00 \mathrm{kcal} / \mathrm{g}$ dry weight, and the rest of the diet a value of $5.82 \mathrm{kcal} / \mathrm{g}$ dry weight, following $\mathrm{Gib} \mathrm{b}$ (1957) and $\mathrm{Kitchell} \& \mathrm{~N}$ orris $(1969$, unpublished, quoted in $\mathrm{Kummins}$ \& W u y check, 1969) then the energy entering the two shrew populations can be calculated. In the case of the common shrew this value is $31,912 \mathrm{kcal} / \mathrm{ha} / \mathrm{annum}$, and in the case of the pigmy shrew $20,031 \mathrm{kcal} /$ /ha/annum. If the assimilation efficiency of the two species is assumed to

Table 6

Some energetic parameters of $S$. araneus and $S$. minutus populations. All values in $\mathrm{kcal} / \mathrm{ha}$ unless otherwise stated.

\begin{tabular}{lcccc}
\hline Months & J.F.M. & A.M.J. & J.A.S. & O.N.D. \\
\hline & S. araneus & & & \\
Biomass, g & 47.7 & 50.4 & 72.0 & 56.7 \\
$\begin{array}{l}\text { Consumption (dry wt., g) } \\
\text { Calorific contribution of }\end{array}$ & 1193 & 1274 & 1840 & 1449 \\
earthworm, enchytraeid and & & & & \\
molluscan diet fraction & 1944 & 1427 & 3338 & 4970 \\
Calorific contribution of mixed & & & & \\
insect diet fraction & 4663 & 5771 & 7176 & 2623 \\
Total consumption & 6607 & 7198 & 10514 & 7593 \\
Faecal loss & 661 & 720 & 1051 & 759 \\
Heat loss & 5710 & 6100 & 8810 & 6948 \\
Total loss & 6371 & 6820 & 9861 & $\mathbf{7 7 0 2}$ \\
Total production & +236 & +378 & +653 & -114 \\
& $S$. minutus & & & \\
Biomass, g & 16.0 & 26.8 & 39.6 & 18.0 \\
Consumption (dry wt., g) & 540 & 915 & 1366 & 621 \\
Total consumption & 3143 & 5323 & 7951 & 3614 \\
Faecal loss & 314 & 532 & 795 & 361 \\
Heat loss & 2590 & 4390 & 6558 & 2981 \\
Total loss & 2904 & 4922 & 7353 & 3342 \\
Production & +239 & +401 & +598 & +272 \\
Annual Consumption (C) & Annual Production $(P)$ & & P/C \\
$\quad$ 31,912 kcal/ha & 1,153 kcal/ha & 0.03 & S. araneus \\
$\quad$ 20,031 kcal/ha & 1,509 kcal/ha & 0.08 S. minutus \\
\hline
\end{tabular}

be the same as that for C. suaveolens in the presence of water (i.e. $90 \%$ ), then it can be seen that contributions to the decomposer chain via faeces will be $3,191 \mathrm{kcal} / \mathrm{ha} / \mathrm{annum}$ and $2,003 \mathrm{kcal} / \mathrm{ha} / \mathrm{annum}$ in the case of common and pigmy shrews respectively.

If the average heat loss per day from the common shrew is taken as $1.33 \mathrm{kcal} / \mathrm{g}$ and that for the pigmy shrew as $1.8 \mathrm{kcal} / \mathrm{g}$, the annual heat losses per hectare may be calculated; these are $27,568 \mathrm{kcal}$ in the case 
of the common shrew and $16,519 \mathrm{kcal}$ in the case of the pigmy shrew. Although these figures are only approximate they do enable one to gain an estimate of the total annual production of shrew populations; 1,153 $\mathrm{kcal} / \mathrm{ha} / \mathrm{annum}$ and $1,509 \mathrm{kcal} / \mathrm{ha} / \mathrm{annum}$ for the common and pigmy shrews respectively.

No account is taken in these figures of urine production and the figure represents total production in terms of growth, production of new individuals, lactation, moult (which occurs at least twice annually in Britain, Pernetta, 1976; three times in Poland, B orowski, 1973) and other epidermal losses.

If the ratio of production to consumption is calculated it is found to be 0.03 and 0.08 for the common and pigmy shrew respectively (Table 6). Both of the values are higher than similar ratios in other species, which tend to fall around 0.02 . This suggests either that the figures for annual consumption are higher than expected on the basis of the available information or that the figures for respiratory losses should be higher, or that urinary losses are appreciable. It would seem likely that any errors can be attributed to the two latter reasons since no account is taken of the urinary losses, and field respiratory losses are likely to be higher than those measured in the laboratory, since activity is greater in an unrestricted environment.

\section{DISCUSSION}

Figure 3 shows the fate of energy entering and leaving the shrew populations each year. One of the problems associated with these animals is that they cannot be easily assigned to any single trophic level since their energy requirements are drawn from diversified sources. If the opiliones, spiders and adult coleoptera are arbitrarily assigned to the secondary consumer level, the earthworms, molluscs, enchytraeids and larvae to the decomposer cycle, we can see that the annual consumption in the case of the common shrews is based on the secondary consumers and decomposers, in the proportion $3: 2$. In the pigmy shrew however the decomposers play a minor role. Such an arbitrary assignment is obviously a gross oversimplification in that many of the larvae are predatory, and many of the adult coleoptera are either primary consumers, or tertiary consumers which themselves may be based at least in part on decomposer organisms. As a broad generalisation however this picture displays the inherent difficulties in the practical application of the trophic dynamic concept of ,ecology in determining the position of the shrews, whilst at the same time giving an indication of the shrew's position.

Such a complexity in the trophic position of shrews suggests that the 
insectivorous habit should be treated as ecologically distinct from the carnivore habit; the anatomy, behaviour and ecology of the two life styles resulting in different selection pressures.

If the assimilation efficiency quoted in this paper and those of B uckner (1964) are correct then it may be that the production/ /consumption ratio is indeed considerably higher than that of carnivores. Several reasons may be advanced in support of this; firstly shrews have a short life span, maximum 12-14 months ( $\mathrm{M}$ i c hi els on, 1966; Pernetta, 1973; Shillito, 1965); and secondly their food source is much less stable than that of most carnivores. Although it is well known that many small mammal populations fluctuate in numbers in a cyclic

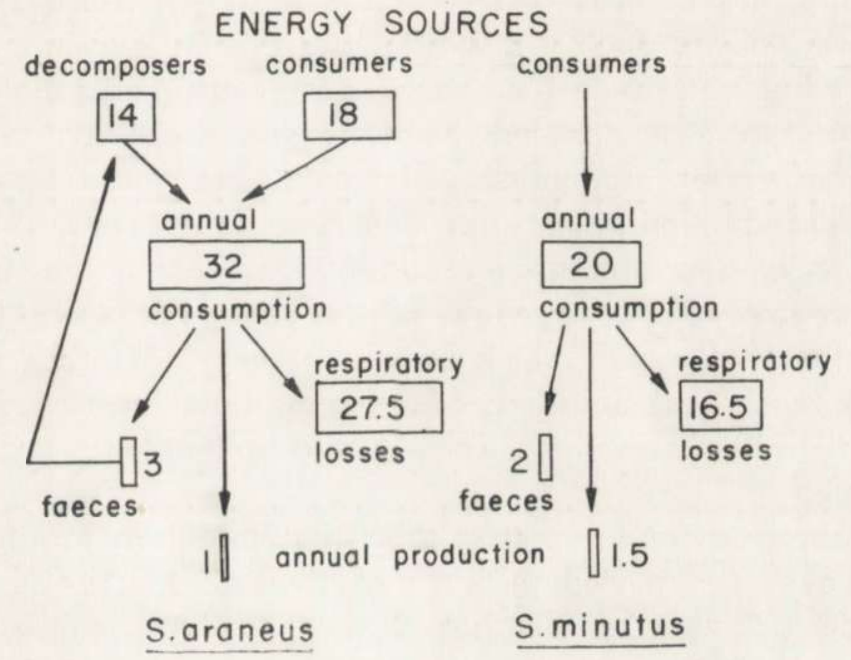

Fig. 3. Energy pathways in Wytham shrew populations.

Values given in thousands $\mathrm{kcal} / \mathrm{ha} / \mathrm{annum}$; to the nearest $500 \mathrm{kcal}$.

fashion (E 1 to $\mathrm{n}, 1942$ ) and in doing so cause similar though delayed fluctuations in their predators, little is known concerning the effect of unpredictably fluctuating food sources on vertebrate populations. Other vertebrate insectivores include predators of winged insects such as the bats, which hibernate over the winter period of food shortage; swifts swallows martins etc., which migrate to warmer climates; and in other geographic areas, specialists on particular insect groups such as termites, ants, etc. Many passerine birds in the temperate zones for example use insects as a high protein food source for the nestlings thus using them for only part of the year. Moles, which are closely related to shrews both in their taxonomic and phylogenetic position specialise on soil invertebrates 
particularly earthworms, their adaptation to a subterranean existence enables them to follow the movements of prey in the soil. Shrews on the other hand are directly affected by fluctuations both in numbers of prey and their availability, the effect of earthworm availability on the remainder of the diet of the common shrew has been well demonstrated (Pernetta, 1973). The work of Tupikova (1949), R udge (1968), Yudin (1962), Lavrov (1943), M ezhzherin (1958), Folit a rek (1940) has shown that the nature of shrews diets are largely determined by invertebrate prey availability, itself a reflection of season, habitat and geographic location. To what extent the often rapid and violent fluctuations observed in many invertebrate populations affect the shrews is unknown; what is known is that the density, distribution and abundance of small insectivores varies from year to year, locality to locality and season to season. Such a mozaic pattern of shrew abundance would suggest that fluctuations in food sources are continually altering the relative favourability of different habitats and areas. It could well be argued that a vertebrate under such conditions would be expected to have a high production to consumption ratio to ensure survival of the population. Selection pressures on individuals for successful breeding must be extremely great in view of the short life span; their reproductive biology' suggests ( $\mathrm{T}$ a rkow ski, 1956; 1957) that they are in fact geared to the maximum production of new individuals, any mechanism which increases this success would undoubtedly be selected for, hence the high $P / C$ ratio.

One further point of interest is the negative figure for production in $S$. araneus over the period October to December. This is very likely correct since it is well known that the body weight, length, and weight of the internal organs of these animals decreases over winter (B o r o wski \& Dehnel, 1953; Crow croft, 1957; Pucek, 1970). In fact it is known that the body length decrease results from regression of the inter-vertebral discs (Hyvärinen, 1969). Such changes in morphometric parameters are well known to occur in many species, which would suggest that the production figures for $S$. minutus are too high. In both species however peak production occurs during the summer months, corresponding to the period of peak production and growth of young animals.

Taking a calorific value of $5 \mathrm{kcal} / \mathrm{g}$ biomass for $S$. araneus and $S$. minutus body material (M y r h a, 1969) it is possible to calculate the theoretical number offspring produced/ha if total production from April to September went into the production of offspring. This is 32 in the case of $S$. araneus and/in the case of $S$. minutus, representing 12 young/female for the former species but $30 /$ female for the latter. Whilst the figure 
for $S$. araneus is reasonable representing just under two litters/female/ /year that for $S$. minutus is not, which further suggests that the figures for production in $S$. minutus are too high. An increase in an individuals daily heat loss of $5 \%(=0.1 \mathrm{kcal} / \mathrm{g} /$ day $)$ or a decrease in food intake of $6 \%(0.4 \mathrm{~g} /$ animal/day, wet weight $)$ gives an annual production of the order of $600 \mathrm{kcal} / \mathrm{ha}$ annum and hence a $P / C$ ratio of 0.028 for this species. This illustrates the difficulties inherent in the use the energetic approach to ecology, in that laboratory measurements are necessary to complete the equations for energy flow, and a small error in such measurements may alter the resultant picture quite dramatically.

Acknowledgements: The author wishes to gratefully acknowledge the financial support provided by the Christopher Welch Biological Trust from 1969 to 1972, and to thank Dr. J. Phillips on, and Professor J. W. S. Pringle for permission to work in the Animal Ecology Research Group and the Department of Zoology respectively. Finally thanks must go to Dr. R. A bel for performing the calorific measurements, Miss H. Cook for technical assistance and to Drs M. J. Co e and J. Phillipson for constructive criticism of the earlier drafts of this paper.

\section{REFERENCES}

1. Babcock H. L., 1914: Some observations on the food of the short-tailed shrew. Science, 40: 526-530.

2. B los S o m P. M., 1932: A pair of long tailed shrews (Sorex cinereus cinereus) in captivity. J. Mammal., 13: 136-143.

3. Borowski S. \& Dehnel A., 1952: Materiały do biologii Soricidae. Annls. Univ. M. Curie-Skłod., 7, 6: 305-448.

4. B or owski S., 1973: Variation in coat and colour in representatives of the genera Sorex L. and Neomys Kaup. Acta theriol., 18: 247-279.

5. Buckner C. H., 1964: Metabolism, food capacity and feeding behaviour in four species of shrews. Canad. J. Zool., 42: 259-279.

6. Buchalczyk A., 1972: Seasonal variations in the activity of shrews. Acta theriol., 17: 221-243.

7. Conaway C. H., 1952: Life history of the water shrews (Sorex palustris navigator). Amer. Midl. Nat., 48: 219-248.

8. Crowcroft P., 1954: The daily cycle of activity in British shrews. Proc. zool. Soc. Lond., 123: 715-729.

9. Crowcroft P., 1957: The life of the shrew. Methuen: 1-166. London.

10. Elton C. H., 1942: Mice, voles and iemmings - Problems in population dynamics. 1-496. Oxford.

11. Folitarek S. S., 1940: A contribution to the biology of the common shrew. Zool. Ž., 19, 2: 324-325. [In Russian with English summ.].

12. Gębczyński M., 1965: Seasonal and age changes in the metabolism and activity of the common shrew Sorex araneus (L in n a e us, 1758). Acta theriol., 10: $303-331$.

13. Gębczyński M., 1971: The rate of metabolism of the lesser shrew. Acta theriol., 15: $329-339$.

14. Gibb J., 1957: Food requirements and other observations on captive tits. Bird Study, 4: 207-215.

15. H a milt on W. J., Jr, 1930: The food of the Soricidae. J. Mammal., 11: 26-39. 
16. Hamilton W. J., Jr, 1941: The food of small forest mammals in the Eastern United States. J. Mammal., 22: 250-263.

17. Hawkins A. E., Jewell P. A. \& Tomlinson G., 1960: The metabolism of some British shrews. Proc. zool. Soc., Lond., 135: 99-103.

18. Hawkins A. E. \& J e well P. A., 1962: Food consumption and energy requirements of captive British shrews and the mole. Proc. zool. Soc. Lond., 138: $137-155$.

19. Heptner J. G., 1939: The Turkestan desert shrew, its biology and adaptive peculiarities. J. Mammal., 20: 39-149.

20. Hyvärinen H., 1969: On the seasonal changes in the skeleton of the common shrew (Sorex araneus L.) and their physiological background. Aquilo, Ser. Zool., 7: 1-32.

21. Kitchell J. B. \& Norris J. S., 1969: Unpublished data, quoted in: Cummins, K. W. \& Wuycheck J. C. Calorie equivalents for investigations in ecological energetics. Pymatuning Lab. of Ecol. Univ. Pittsburg, Mimeo.

22. Kostelecka-Myrcha A. \& Myrcha A., 1964: Rate of passage cf foodstuffs through the alimentary tract of Neomys fodiens ( $\mathrm{P}$ e n n a $\mathrm{n}, 1771$ ) under laboratory conditions. Acta theriol., 9, 20: 371-373.

23. Lavrov N. F., 1943: On the biology of the common shrew, Sorex araneus L. Zool. Ż., 22: 361-365 [In Russian with English summ.].

24. Mezhzherin V. A., 1958: On the feeding habits of Sorex araneus and Sorex minutus. Zool. Ż., 37: 948-953 [In Russian with English summ.].

25. Michielson N. C., 1966: Intraspecific and interspecific competition in the shrews Sorex araneus L. and S. minutus L. Arch. Neerl Zool., 17, 1: 73-174.

26. Morrison P. R., Pierce M. \& Ryser F. A., 1957: Food consumption and body weight in the masked and short-tailed shrews. Am. Midl. Nat., 57: 493-501.

27. Myrcha A., 1969: Seasonal changes in caloric value, body weight and fat in some shrews. Acta theriol., 16: $211-227$.

28. Pernet t a J. C., 1973: D. Phil. Thesis, Univ. of Oxford. Msc.

29. Pernetta J. C., 1976: A note on the moult of Sorex araneus and Sorex minutus with observations on the patch mouths of Crocidura suaveolens. J. Zool., Lond. 179: 216-219.

30. Pernetta J. C., 1976: The diets of Sorex araneus and Sorex minutus in Wytham grassland. J. Anim. Ecol. (In press).

31. Pucek Z., 1964: Morphological changes in shrews kept in captivity. Acta theriol., 8: 137-166.

32. Pucek Z., 1970: Seasonal and age changes in shrews as an adaptive process. Symp. zool. Soc. Lond., 26: 189-207.

33. Rörig G., 1905: Uber den Nahrungsverbrauch einer Spitzmaus. Arb. Kaiserl Gesundh. Amt., Berlin, Biol. Abt., 4: 121-122.

34. Rudge M. R., 1968: The food of the common shrew, Sorex araneus L. (Insectivora, Soricidae) in Britain. J. Anim. Ecol., 37: 565-581.

35. Shillito J., 1960: The general biology of the common shrew, Sorex araneus L. Unpubl. D. Phil. thesis, University of Exeter.

36. Shull A. F., 1907: Habits of the short-tailed shrew, Blarina brevicauda. Amer. Midl. Nat., 41: 495-522.

37. Springer S., 1937: Observations on Cryptotis floridana in captivity. J. Mammal., 18: 237-283.

38. Svihla A., 1934: The mountain water shrew. Murrilet, 15: 44-45. 
39. Tarkowski A. K., 1956: Studies on reproduction and prenatal mortality, of the common shrew (Sorex araneus L.). Part 1. Foetal regression. Annals Univ. M. Curie-Skłodowska, C, 9: 387-429.

40. Tarkowski A. K., 1957: Studies on reproduction and prenatal mortality of the common shrew (Sorex araneus L.). Part 2. Reproduction under natural conditions. Ibid, 10: 177-244.

41. Tupıkova N. V., 1949: The diet and nature of the daily cycle of activity of shrews from central U.S.S.R. Zool. Ž., 28: 361-572. [In Russian with English summ.].

42. Vogel P., 1976: Energy consumption of European and African shrews. Acta theriol., 21: 195-205.

43. W o łk E., 1969: Body weight and daily food intake in captive shrews. Acta theriol., 14: $35-47$.

44. Yudin B. S., 1962: [Ecology of shrews (genus Sorex) of Western Siberia]. Tr. biol. inst., Sibir. otd. AN SSR, 8: 33-134.

Accepted, April 24, 1976.

John C. PERNETTA

\section{BIOENERGETYKA RYJOWEK ZAMIESZKUJĄCYCH MURAWY}

\section{Streszczenie}

W warunkach laboratoryjnych zmierzono konsumpcję dobową, tempo przechodzenia treści pokarmowej i ilość wydalanego kału u Sorex araneus, Sorex minutus i Crocidura suaveolens cassiteridum (Tabele 2, 4). Wykazano, że podawane w literaturze (Tabela 1, Ryc. 1) rozbieżności co do wielkości zużycia pokarmu przez ryjówki są, przynajmniej w części, powodowane różną zawartością wody w sztucznych dietach. Współczynnik strawności u C. suaveolens wynoszący $89 \%$ jest podcbny jak u wielu innych gatunków ryjówek. Wskaźnik ten ulega podwyższeniu jeśli zwierzęta pozbawi się dostępu do wody.

Diagram (Ryc. 3) przedstawiający przepływ energii przez populację ryjówek zamieszkujących murawy kserotermiczne $\mathrm{z}$ Brachypodium pinnatum $\mathrm{w}$ okolicach Wytham w Anglii, oparto na analizie pokarmu u $S$. araneus (244 osobników) i $S$. minutus (130 osobników) złapanych w pułapki zabijające (Tabela 3). Przedstawiono też konsumpcję $(C)$ i produkcję $(P)$ roczną (Tabele 5,6 ) dla obu tych gatunków i dokonano próby objaśnienia wysokiego stosunku $P$ do $C$. 
gryzoniami feromonów (E. Christiansen i K. Døving) a także oddziaływaniami na hormonalną regulację rozrodu (P. Meurling i E. Nyholm).

Na wybranych przykładach Microtus agrestis i Arvicola terrestris (A. Myllymäki) oraz myszy i szczurów (M. Lund) omówiono postęp badań w zakresie poznania socjalnych stosunków w populacjach tych ssaków, interakcji międzygatunkowych i możliwości oddziaływania na te struktury i procesy populacyjne w celu ograniczenia liczebności.

Pojawianie się populacji odpornych na działanie chemosterylantów zmusza do poszukiwania innych metod, przy czym jednak użycie metod genetycznych nie jest bardziej obiecujące niż konwencjonalnych (O. Halkka, M. Rasmuson). Przegląd metod oceny liczebności drobnych ssaków (A. Myllymäki) oraz opis systemu gromadzenia danych dla celów prognostycznych (B. Hörnfeldt) zamykają tę część książki.

Końcowe rozdziały obejmują przegląd aktualnych badań, wytyczają kierunki przyszłych studiów. Za najważniejsze uważa sie przy tym: (1) poznanie skutków działania człowieka w środowisku, (2) badanie odporności roślin na zgryzanie przez gryzonie, (3) rola stosunków socjalnych, w tym też feromonów, behawioru i mechanizmów fizjologicznych w regulacji liczebności populacji, (4) poszukiwanie środków chemicznych skutecznych dla zwalczania gryzoni ale nie powodujących skażeń środowiska, (5) ocena roli patogenów i pasożytów, oraz (6) wypracowanie systemu dokumentacji (szkód, prognozowania itp.).

Liczni autorzy i redaktorzy książki dają wyraz temu, że doceniają znaczenie podstawowych badań ekologicznych dla walki biologicznej ze szkodliwymi gryzoniami. Proporcje książki i zakres prezentowanego w niej materiału dobitnie jednak świadczy, że faktyczny dorobek w tym zakresie jest dotychczas raczej skromny. Książka daje przegląd istniejącego stanu badań w'zakresie zwalczania szkodliwych gryzoni i owadożernych. Zasadniczym jej walorem jest kompleksowe potraktowanie problemu i skierowanie uwagi na metody walki biologicznej. Należy żywić nadzieję, iż będzie to działało stymulująco na przyszłe badania w tym zakresie.

Książka jest cenną pozycją współczesnej literatury teriologicznej, stanowi dobre kompendium wiedzy na temat zwalczania drobnych ssaków, przydatne dla studentów i wszystkich zainteresowanych tymi problemami. 